\title{
SPECIFIC FEATURES OF WATER INFILTRATION INTO SOIL WITH DIFFERENT MANAGEMENT IN WINTER AND EARLY SPRING PERIOD
}

\author{
STANISLAV HEJDUK, KLAUDIUS KASPRZAK \\ Mendel University in Brno, Zemědělská 1, 61300 Brno, Czech Republic; Mailto: hejduk@mendelu.cz
}

\begin{abstract}
The paper deals with the effects of agricultural soils management on surface runoff in winter and early spring period. Cryogenic processes that take place in soils can cause temporary reduction of infiltration capacity of soil. In the periods of snow-thawing and rain these phenomena induce conditions promoting the occurrence of surface runoff and floods.

Effects of agricultural soils management on surface runoffs were studied at the research station in BrnoKníničky, Czech Republic, from 1965 to 2002. The aim of this research was to find out the differences between the winter surface runoff from experimental plots under winter wheat crop sown after plowing and under perennial forage crops without tillage. On soils without plowing, the decrease of soil infiltration rate occurred faster and was more intensive than on loose soils. During ten winter periods the average surface runoff from perennial forages was significantly higher (2.05 times) than from wheat crop (runoff coefficients 0.239 vs. 0.489 ).
\end{abstract}

KEY WORDS: Infiltration, Cryopedosphere, Surface Runoff, Thawing and Freezing, Soil Tillage, Grassland.

Stanislav Hejduk, Klaudius Kasprzak: ZVLÁŠTNOSTI VODNÍHO REŽIMU ZEMĚDĚLSKÝCH PŮD V ZIMĚ A V PŘEDJAŘí. J. Hydrol. Hydromech., 58, 2010, 3; 17 lit., 1 obr. 3 tab.

Př́spěvek se zabývá hodnocením vlivu kultivace zemědělských půd na povrchové odtoky v zimním a předjarním období. Kryogenní procesy v půdách mohou způsobovat dočasnou redukci jejich infiltrační rychlosti. V obdobích tání sněhu a deštů vytváří podmínky pro výskyt povrchového odtoku a povodní.

V letech 1965-2002 byl sledován na výzkumné stanici v Brně-Kníničkách vliv kultivace zemědělských půd na povrchové odtoky. Cílem tohoto výzkumu bylo najít rozdíly mezi zimními povrchovými odtoky z pokusných ploch $\mathrm{s}$ ozimou pšenicí vysetou po orbě a s víceletými pícninami bez zpracovaní půdy. Na půdách bez orby došlo $\mathrm{k}$ redukci infiltrační rychlosti rychleji a tato redukce byla intenzivnější než na kyprých půdách po orbě. Během deseti hodnocených zimních období byl povrchový odtok $\mathrm{z}$ víceletých pícnin průkazně vyšší ( 2,05 krát) než z pšenice. Prủměrný koeficient povrchového odtoku u ozimé pšenice dosáhl hodnoty 0,239 a u víceletých pícnin 0,489 .

KLÍČOVÁ SLOVA: infiltrace, kryopedosféra, povrchový odtok, tání a mrznutí, obdělávání půdy, travní porost.

\section{Introduction}

In temperate and transient subtropical and subarctic zones as well as in mountain regions with a vertically differentiated climate, the periods of decreasing air temperature are usually associated with a soil temperatures decrease. The result of a gradual penetration of below-zero temperatures into the soil is its freezing. The thickness and water content of seasonally frozen soil layers determine a water balance of land units in the landscape in winter and early spring period.
The surface runoff from agricultural land is considered to be a harmful phenomenon, which cause local (and in winter seasons also regional) floods. It is the cause of erosion and moisture deficit on slopes; while on the flatland (e.g. in depressions or shallow hollows) causes water logging and, thus, also an undesirable delay of tillage operations or winter crop damage.

In some parts of the world (e.g. northwest of the USA and in Scandinavia) runoff from frozen soil surfaces may be the main risk factor of floods connected with soil erosion (Seyfried and Flerchinger, 
1994; Øygarden, 2003). In arid regions, runoff from frozen soil surfaces reduces the groundwater recharge (Schillinger, 2001). Improved tillage methods can potentially be developed to increase the rate of infiltration of winter precipitation (Pikul et al., 1996; Kaljužnyj and Pavlova, 1988). On the other hand, phenomena taking place both in and on the frozen soil show only a small effect on hydrological processes in mountainous areas, where the depth of snow cover can be even more than $10 \mathrm{~m}$ in some localities (Hejcman et al., 2006).

The mechanism of surface runoff from frozen soil differs considerably from that which occurs after downpours on non-frozen soil (Fohrer et al., 1999). It is therefore not possible to use the same prediction models in both cases, for example the CN method ( $\mathrm{McC}$ Cool et al., 1995). Whereas prediction of surface runoff on non-frozen soil requires knowledge of the intensity and duration of rainfall and the properties of a soil surface crust, runoff models for frozen soil surface require data about thickness of frozen layer, water distribution in soil, and number of periods of thawing and freezing (Hayhoe et al., 1993; Stähli et al., 1996).

This paper does not present an exhaustive description of the frozen horizon development. These problems are discussed in detail in many publications on the relatively young scientific discipline cryopedology, which has been developed principally by Russian, American, Canadian and Scandinavian scientists (e.g. Sokolov et al., 1980; Nazarov, 1981; Palagin, 1988; Schillinger, 2001; Stähli et al, 1996; Øygarden, 2003 and others).

This research was focused on formation of surface runoff from agricultural land after winter precipitations. The objective was to estimate the proportion of surface runoff resulting from winter precipitations on loose loamy soils (winter cereal crops sown after plowing) and on settled soils (perennial forages) to explain the changes in infiltration rate of these soils during the winter season. Another objective of this research was to contribute to the explanation of winter precipitations participation in the accumulation of soil water and ground water in the pre-growing period.

\section{Material and methods}

Effects of frost on water regime of agricultural soils were studied on a research station in BrnoKníničky, Czech Republic (49 14'1.3" N; $\left.16^{\circ} 31^{\prime} 39^{\prime \prime} \mathrm{E}\right)$, since 1965 to 2002 . The system consisted of six rectangular plots $(5 \times 4 \mathrm{~m})$ exposed southwards and arranged into three pairs $(\mathrm{A}, \mathrm{B}, \mathrm{C})$, which differed in slope $\left(\mathrm{I}_{\mathrm{A}}=8 \%, \mathrm{I}_{\mathrm{B}}=3 \%, \mathrm{I}_{\mathrm{C}}=12\right.$ $\%)$. In the lower part each plot, a concrete gutter was connected to a reservoir enabling collection and measuring of surface runoff. The soil in these model catchment areas was classified as a silt loam, orthic luvisol. Runoff phenomena were studied with regard to the crop and tilling operations. In the course of the experiment, the crops were changed in accordance with the objectives of the research projects. This paper analyzes ten winter seasons when the experimental runoff plots were covered by simultaneously grown winter wheat (sown after deep tillage to $200 \mathrm{~mm}$ ) and perennial forages (grassland, ley or alfalfa - no tillage). The perennial forages were cut three to four times per year.

The following parameters were evaluated: runoff coefficient $\varphi_{o}$ and infiltration coefficient $\varphi_{i}$; the former was defined as the ratio of height of surface runoff $\left(H_{\mathrm{o}}\right)$ to the given precipitation $\left(H_{s}\right)$ while the latter as a ratio of the height of infiltrated water layer $\left(H_{i}\right)$ to the precipitation $\left(H_{s}\right)$. For snow with a smooth surface, the average value of evaporation $0.21 \mathrm{~mm} \mathrm{~d}^{-1}$ (Kasprzak, 1975 in Novák, 1995) was also taken into account.

Data in Fig. 1 (instantaneous $\varphi_{i}$ values) were based on:

1. observation after snow thawing periods, when disappearance of snow cover occurs

2. measuring of surface runoff volumes in periods of winter rains (the most accurate, majority of data, snow water equivalent was measured).

The obtained values of $\varphi_{o}$ were statistically processed using the method of $t$-test for independent samples at the significance level of $P=0.01$. This procedure was used because of considerable differences in meteorological characteristics in particular winter seasons.

\section{Results and discussion}

Meteorological data in 10 individual winter periods and corresponding surface runoffs occurring in stands of winter wheat and perennial forages are presented in Tab. 1. Only 10 individual winter seasons could be used for comparison of surface runoffs between winter wheat and perennial forage crops as during other winter periods these crops were not grown simultaneously. Differences in surface runoff coefficients of these crops and also the depths of frozen soil layer are presented in Tab. 2. 


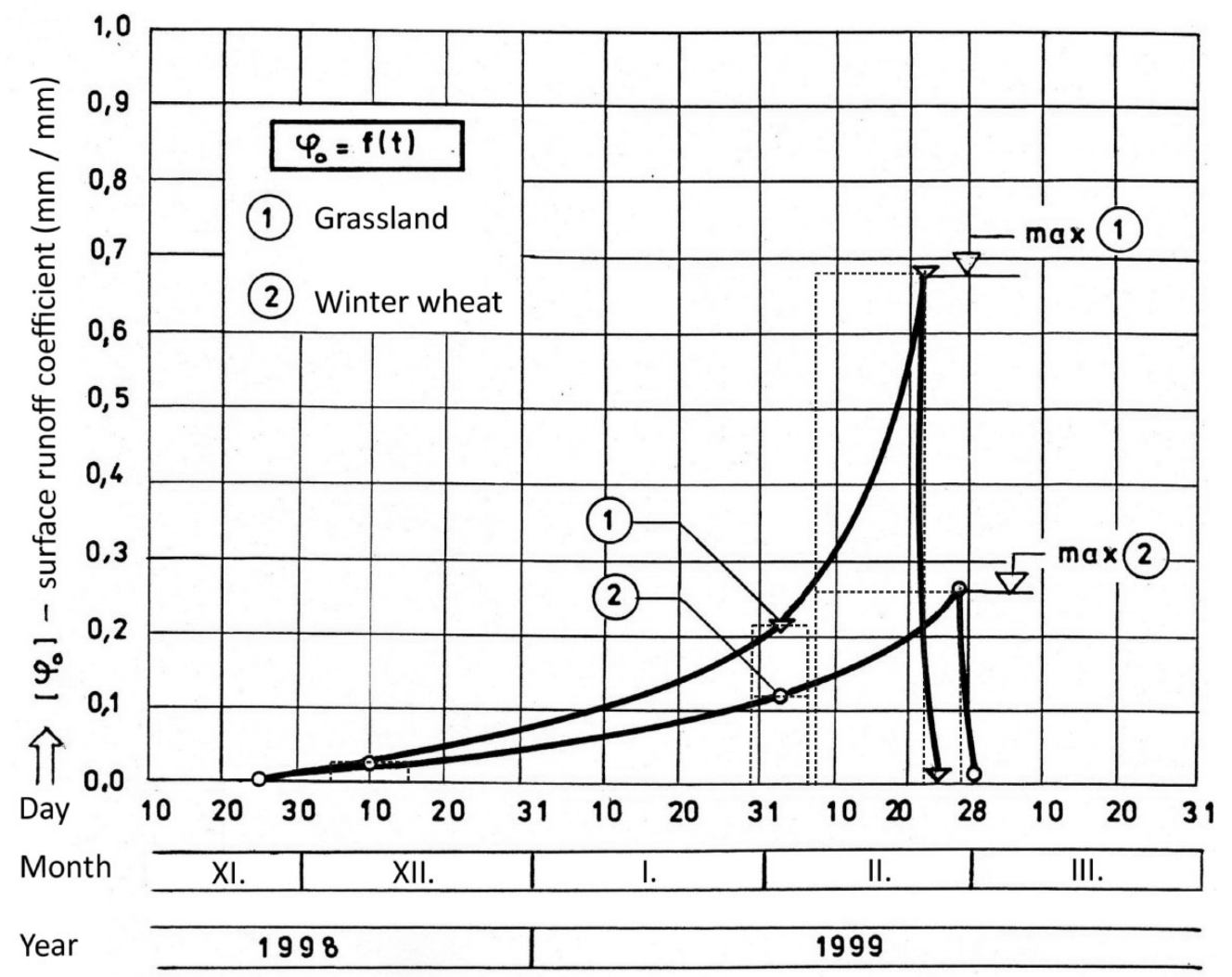

Fig. 1. Time course of changes of the surface runoff coefficients of grassland and winter wheat stands during the winter season of 1998-1999 (inclination $8 \%$ ). The periods for a definition of partial surface runoff coefficient values are displayed by dash lines. Obr. 1. Časový průběh změn koeficientů povrchového odtoku na stanovištích travních porostů a ozimé pšenice během zimního období 1998-1999 (sklon svahu 8 \%). Období pro stanovení hodnoty parciálních součinitelů povrchového odtoku je zobrazeno přerušovanými čarami.

$\mathrm{T}$ a b l e 1. Comparison of winter surface runoff from experimental plots with winter wheat and perennial forage crops. T a b u l k a 1. Porovnání zimních povrchových odtoků z pokusných ploch s ozimou pšenicí a víceletými pícninami.

\begin{tabular}{|c|c|c|c|c|c|}
\hline \multirow[b]{2}{*}{ No. } & \multirow[b]{2}{*}{$\begin{array}{l}\text { Measured period* } \\
\text { from - until }\end{array}$} & \multirow{2}{*}{$\begin{array}{l}\text { Precipitation } \\
{[\mathrm{mm}]}\end{array}$} & \multicolumn{2}{|c|}{ Surface runoff $[\mathrm{mm}]$} & \multirow{2}{*}{$\begin{array}{l}\text { Comment - specifications } \\
\text { (harvest year) }\end{array}$} \\
\hline & & & $\begin{array}{l}\text { winter } \\
\text { wheat }\end{array}$ & $\begin{array}{l}\text { perennial } \\
\text { forage }\end{array}$ & \\
\hline 1. & $3.12 .1965-6.2 .1966$ & 61.4 & 13.3 & 24.3 & Lucerne, $1^{\text {st }}$ year \\
\hline 2. & $27.11 .1978-2.3 .1979$ & 117.6 & 56.5 & 63.3 & Grassland, $1^{\text {st }}$ year \\
\hline 3. & 5. $1.1984-29.2 .1984$ & 100.8 & 19.7 & 52.9 & Grassland, $2^{\text {nd }}$ year \\
\hline 4. & 26.12.1984-8.3.1985 & 81.0 & 34.1 & 62.2 & Grassland, $3^{\text {rd }}$ year \\
\hline 5. & $31.12 .1985-8.3 .1986$ & 59.4 & 19.1 & 45.8 & Grassland, $4^{\text {th }}$ year \\
\hline 6. & 5. 12. $1995-19.3 .1996$ & 118.6 & 19.7 & 63.6 & Lucerne, $2^{\text {nd }}$ year \\
\hline 7. & 20. 12. $1996-20.2 .1997$ & 47.0 & 0.6 & 17.8 & Lucerne, $3^{\text {rd }}$ year \\
\hline 8. & 16. 12. $1998-27.2 .1999$ & 41.1 & 6.5 & 16.4 & Grassland, $2^{\text {nd }}$ year \\
\hline 9. & 19.12. $1999-1.2 .2000$ & 58.2 & 24.1 & 32.2 & Grassland, $3^{\text {rd }}$ year \\
\hline \multirow[t]{2}{*}{10.} & 27. 11. $2001-28.1 .2002$ & 51.8 & 0.0 & 0.1 & Grassland, $5^{\text {th }}$ year \\
\hline & Average & 73.7 & 19.4 & 37.9 & \\
\hline
\end{tabular}

*Period of continuous snow cover, which caused surface runoff

*Období s trvalou sněhovou pokrývkou, která vyvolala povrchový odtok

The process of decreasing permeability of soil, which begins after the permanent onset of negative temperatures, results from its increasing water con- tent and blocking of soil pores by ice. There are two major sources of water for the formation of impermeable ice layer in soil: 
- Water from thawing snow and/or from rainfalls occurring during episodic thaws (i.e. a discontinued supply of soil water)

- Water migrating from deeper (unfrozen) soil layers towards the freezing front (i.e. a continual supply, which takes place during the whole period of frozen soil).

The permeability of frozen soil depends on the volume and continuity of air filled pores. In soils loosened by plowing (i.e. in stands of winter wheat), the proportion of these coarse pores is relatively high so that the amount of water necessary for their blockade is much higher than in settled soils with a predominating proportion of capillary pores (i.e. in perennial forage crops, grassland and stubble fields). This means that in loose soils the process of filling up of free pores and of a gradual reduction of infiltration capacity of soil is much slower than in compact, settled soils (Tab. 3). After a rainy autumn, when the content of water in freez- ing soil is high, the decrease in infiltration rate begins immediately after the freezing of both loose and settled soil (Fig. 1).

Freezing of soils is often accompanied by the formation of ice layers and/or ice lenses which can be several centimeters thick. Occurrence of these formations indicates a significant reduction of infiltration rate of frozen soils. Their formation is closely related to the phenomena taking place when the soil water migrates from the lower unfrozen layers to the freezing front of and is transformed to ice. The different forms of ice in the frozen soil were described by Trimble et al. (1972).

In all winter periods under study, surface runoffs from perennial forages were higher than those from winter wheat stands. It is assumed that the reasons of this phenomenon were increased air-filled soil porosity and a decreased intensity of upward water migration (capillary rise) in winter wheat stands.

$\mathrm{T}$ a b 1 e 2. Comparison of surface runoff coefficients $\varphi_{\mathrm{o}}$ of winter wheat and perennial forage crops (water evaporation from the snowpack is deducted).

$\mathrm{T} \mathrm{a} \mathrm{b} \mathrm{u} 1 \mathrm{k}$ a 2. Porovnání koeficientů povrchového odtoku $\varphi_{\mathrm{o}} \mathrm{z}$ ozimé pšenice a víceletých pícnin (výpar vody ze sněhové pokrývky byl odečten).

\begin{tabular}{lccc}
\hline Winter period & Winter wheat & Perennial forage & $\begin{array}{c}\text { Maximal depth of freezing } \\
\text { front [mm] }\end{array}$ \\
\hline $1965 / 1966$ & 0.216 & 0.398 & 460 \\
$1978 / 1979$ & 0.480 & 0.538 & 550 \\
$1983 / 1984$ & 0.196 & 0.525 & 350 \\
$1984 / 1985$ & 0.421 & 0.768 & 400 \\
$1985 / 1986$ & 0.321 & 0.771 & 450 \\
$1995 / 1996$ & 0.166 & 0.536 & 380 \\
$1996 / 1997$ & 0.012 & 0.379 & 150 \\
$1998 / 1999$ & 0.159 & 0.400 & 150 \\
$1999 / 2000$ & 0.414 & 0.553 & 170 \\
$2001 / 2002$ & 0.000 & 0.020 & 150 \\
Average & 0.239 & $0.489 * *$ & 321 \\
Comparison & $100.0 \%$ & $205.0 \%$ & \\
\hline
\end{tabular}

** - highly significant differences according to $t$-test for independent samples.

** - vysoce průkazné rozdíly podle dvouvýběrového $t$-testu.

$\mathrm{T} \mathrm{a} \mathrm{b} 1$ e 3. Typical time course of changes of the surface runoff coefficients of grassland and winter wheat stands during the winter season of 2002-2003

$\mathrm{T} \mathrm{a} \mathrm{b} \mathrm{u} 1 \mathrm{k}$ a 3 . Typický časový průběh změn koeficientů povrchového odtoku na stanovištích travních porostů a ozimé pšenice během zimního období 2002-2003.

\begin{tabular}{|c|c|c|c|c|c|}
\hline \multirow[b]{2}{*}{ Period } & \multirow{2}{*}{$\begin{array}{c}\text { Precipitation } \\
{\left[H_{s}=\mathrm{mm}\right]}\end{array}$} & \multicolumn{2}{|c|}{$\begin{array}{c}\text { Surface runoff } \\
{\left[H_{\mathrm{o}}=\mathrm{mm}\right]}\end{array}$} & \multicolumn{2}{|c|}{$\begin{array}{c}\text { Surface runoff coefficient } \\
{\left[\varphi_{\mathrm{o}}=\mathrm{mm} / \mathrm{mm}\right]}\end{array}$} \\
\hline & & wheat & grassland & wheat & grassland \\
\hline $9.11 .-9.11$. & 8.2 & 0.0 & 0.0 & 0.0 & 0.0 \\
\hline 11. 11. - 11. 11 . & 6.1 & 0.0 & 0.0 & 0.0 & 0.0 \\
\hline 16. 12. -31.1 . & 66.8 & 25.4 & 40.5 & 0.381 & 0.607 \\
\hline 16. 12. - 2. 3. & 72.5 & 29.1 & 46.1 & 0.401 & 0.636 \\
\hline 3. 2. -2.3 . & 5.7 & 3.7 & 5.6 & 0.645 & 0.978 \\
\hline 4. $3 .-4.3$. & 0.6 & 0.0 & 0.0 & 0.0 & 0.0 \\
\hline
\end{tabular}


This then resulted in a higher requirement of water for filling of soil pores and in their later blockade by ice compared to settled soil of perennial forages (it means postponed term of an onset of surface runoffs). In loosened (i.e. ploughed) soil the thickness of water-saturated frozen horizon was greater and duration its impermeable state was shorter than in settled soils without cultivation. This means that a higher percentage of winter precipitation could infiltrate into the ploughed soil.

On the other side, extensively managed grasslands (one or two cuts per year) create favourable microclimate for edaphon, resulted in higher proportion of soil macropores providing reduction of surface runoffs both, in winter and in summer seasons. The total surface runoffs from those stands are lover than from conventional grasslands and can be even lower than from arable land (Hejduk, 2009).

Reliability and authenticity of simulated tillage measures was corroborated by the fact that, on experimental plots, the runoffs occurred always in the same time intervals and that its duration was the same as on the neighboring agricultural fields managed by means of conventional agricultural methods.

Generally, the seasonal runoff coefficients $\varphi_{o}$ at stand Brno-Kníničky were much higher in comparison to those recorded at higher altitude of Bohemian-Moravian Upland with deep snow pack and shallower soil frost penetration (Hejduk, 2009).

The intensity and degree of cryogenic reduction of infiltration rate of soil is also dependent on antecedent soil water content, duration and value of air temperatures below zero, on character of precipitation (rain or snow) and on the presence or absence of autumn mechanical cultivation. On soils without cultivation, the decrease of infiltration rate occurs faster and to a higher degree than on cultivated soils. However, there are some phenomena which shade the effect of mechanical cultivation such as prolonged freezing temperatures or frequent episodic thaws with rains. Such weather conditions accentuate surface runoff on slopes and lead to waterlogging in alluvia and terrain depressions.

As there were three levels of slope used in this experiment, it can be stated that surface runoff was not always higher on more steep slopes. The reason for that is probably more intensive insolation (south inclination) and subsequently shallower frost penetration at steeper slopes. Another reason can be lower water retention on soil surface after short periods of thawing which leads to faster blocking of surface soil porosity on flatland during subsequent freezing period. It can lead in some situation to lover infiltration rates at plain fields in comparison to slopes.

This research was executed in lowland area with relatively low height of snow pack and deeper soil frost penetration compared to higher altitudes. The results of this experiment can not be generalized for all round areas with seasonally frozen soil. In lowlands, there are potentially fertile and deep soils, which are potentially able to retain all, infiltrated water from winter precipitation and provide it to plants in advanced season. Presented results show that in some winter periods more than $50 \%$ of water from thawing snow can be lost by overland flow. Soil tillage is able to reduce these losses significantly.

Considering that in central Europe the majority of climate models predict less rainfalls during the growing season and increased precipitations during the winter, it can be concluded that water losses caused by winter and early spring surface runoff will be further intensified (Dumbrovsky et al., 2005).

Acknowledgement. This study was supported by the Research plan no. MSM6215648905 "Biological and technological aspects of sustainability of controlled ecosystems and their adaptability to climate change", which is financed by the Ministry of Education, Youth and Sports of the Czech Republic.

\section{REFERENCES}

DUBROVSKY M., NEMESOVA I. and KALVOVA J., 2005: Uncertainties in climate change scenarios for the Czech Republic. Climate Research, 29, 139-156.

FOHRER N., BERKENHAGEN J., HECKER J.M., RUDOLPH A., 1999: Changing soil and surface conditions during rainfall single rainstorm/subsequent rainstorms. Catena, 37, 355-375.

GUSEV Ye.M., 1991: Modelling water transfer in soils during the winter-spring period. In: Jienitz, G., Milly, P.C.D., Van Genuchten, M.T., Rosbjerg, D., Shuttleworth, W.J., Hydrological interaction between atmosphere, soil and vegetation. Wallingford, UK, IAHS Publication. pp. 235-244.

HAYHOE H.N., PELLETIER R.G., VLIET L.J.P.van, 1993: Estimation of snowmelt runoff in the Peace Riverregion using a soil moisture budget. Canadian Journal of Soil Science, $73,4,489-501$.

HEJCMAN M., DVOŘÁK I.J., KOCIÁNOVÁ M., PAVLŮ V., NEŽERKOVÁ P., VÍTEK O., RAUCH O. and J. JENÍK, 2006: Snow Depth and Vegetation Pattern in a Late-melting Snowbed Analyzed by GPS and GIS in the Giant Mountains, Czech Republic. Arctic, Antarktis and Alpine Research, 38, 1, 90-98. 
HEJDUK S.,2009: Comparison of surface runoffs from grasslands and arable land. Grassland Science in Europe, 15, 63-67.

KALJUŽNYJ I.L., PAVLOVA K.K., 1988: Formirovanie poter talovo stoka. Gidrometeoizdat.

NAZAROV G.V., 1981: Gidrologičeskaja rol' počvy. Nauka, Moskva.

NOVÁK V., 1995: Vyparovanie vody v prírode a metódy jeho určovania. VEDA, SAV Bratislava, $253 \mathrm{~s}$.

ØYGARDEN L., 2003: Rill and gully development during an extreme winter runoff event in Norway. Catena, 50, 217-242 .

PALAGIN E.G., 1988: Matematičeskoje modelirovanie uslovij perezimovki ozimich kul'tur. Gidrometeoizdat.

PIKUL J.L., WILKINS D.E., AASE J.K., ZUZEL J.F., 1996: Contour ripping: a tillage strategy to improve water infiltration into frozen soil. J. of Soil and Water Conservation, 51, 76-83.

SEYFRIED M.S., FLERCHINGER G.N., 1994: Influence of frozen soil on rangeland erosion. In: SSSA Special Publication No. 38. Variability in rangeland water erosion processes, Minneapolis, p. 67-82.

SCHILLINGER W.F. 2001: Reducing water runoff and erosion from frozen agricultural soils. In: Ascough, I.I., Flanagan, D.C.: Soil erosion research for the $21^{\text {st }}$ century Proceedings of the International symposium, Honolulu, Hawai, USA, 3-5 January 2001, p. 32-35.

SOKOLOV I.A., CHIGIR V.G., ALIFANOV V.M., KHUDYAKOV O.I., GUGALINSKAYA L.A., FOMINIKH L.A., TILCHINSKI D.A., MAXIMOVICH S.V., 1980: Concepts, terminology and classification problems in studiing cryogenic soil. (Ponjatia, terminologija i klassifikacionnye voprosy izučenija promerzajuščich počv.) (In Russian.) Počvovedenie, 12, 118-25.

STÄHLI M., JANSSON P.E., LUNDIN L.C., 1996: Preferential water flow in a frozen soil - a two-domain model approach. Hydrological Processes, 10, 1305-1316.

TRIMBLE G.R., SARTZ R.S., PIERCE, R.S., 1972: How type of soil frost affect infiltration. Journal of Soil and Water Conservation, 13, 2, 81-82.

Received 16. November 2009 Accepted 23. June 2010

\section{ZVLÁŠTNOSTI VODNÍ BILANCE ZEMĚDĚLSKÝCH PŮD V ZIMĚ A V PŘEDJAŘÍ}

\section{Stanislav Hejduk, Klaudius Kasprzak}

Při poklesu teplot vzduchu pod bod mrazu nabývá část pedosféry dočasně charakteru kryopedosféry, která má zápornou teplotu. Dočasná kryopedozóna, její mocnost a vlhkostní stav, se stává významným hydrologickým faktorem, který se v zimním a předjarním období podílí na utváŕení vodního režimu nejen krajiny, ale i celých regionů. $\mathrm{V}$ některých oblastech mohou povrchové odtoky ze zmrzlé půdy představovat hlavní riziko povodní spojených s erozí půdy. Povrchové odtoky ze zamrzlé půdy ochuzují aridní zemědělské oblasti o cennou půdní vodu, a proto se zde hledají agrotechnické způsoby, jak zvýšit podíl infiltrované vody ze srážek spadlých v zimním období.
Mechanismus povrchového odtoku ze zmrzlých půd se značně liší od toho, který se uplatňuje u půd s kladnými teplotami. Není proto možné použít pro oba př́pady stejné predikční modely, např́ílad metodu $\mathrm{CN}$. Predikce povrchového odtoku na nezamrzlé půdě vyžaduje znalosti o intenzitě a době trvání deštových srážek a o existenci a kvalitě krusty na povrchu půdy. Naproti tomu odtokové modely pro zamrzlé půdy vyžadují údaje o hloubce promrznutí, o distribuci vody v půdě a o počtu období tání a oblev.

Výzkum v letech 1966 - 2003 prokázal, že významnou půdní vrstvou vznikající a zanikající v průběhu zimního období v půdním profilu je kryogenní půdní kůra, která má rozhodující význam při formování infiltračních a odtokových procesů na zemědělských půdách v zimním a předjarním období. Proces snižování propustnosti půdy, který se začne uplatňovat po trvalém nástupu negativních teplot vzduchu, vyplývá ze zvyšování vlhkosti půdy a blokování pórů ledem. Existují dva hlavní zdroje vody pro tvorbu nepropustné vrstvy ledu $v$ půdě:

- Voda z tajícího sněhu, popríípadě deštové srážky, které se vyskytly během tání (tj. přerušovaný př́sun půdní vláhy);

- - Voda přicházející z hlubších (nezamrzlých) vrstev půdy $\mathrm{k}$ hranici promrzání (tj. kontinuální př́sun, který probíhá $\mathrm{v}$ průběhu celého období záporných teplot půdy).

Sezonní kryopedozóna je charakterizována pozvolným nárůstem ledovitosti půdy doprovázeným ztrátou propustnosti, dosažením minima a relativně náhlým poklesem a zánikem ledovitosti. Při vzniku ledové podpovrchové vrstvy se výrazně uplatňuje vzestupný kapilární př́tok vody $\mathrm{z}$ hlubších, nezmrzlých vrstev půdy. Proto proces kryogenní redukce propustnosti půdy probíhá rychleji na půdách ulehlých (stanoviště vojtěšky, travních porostů, strništ'), než na půdách kyprých (ozimy po orbě). Během deseti hodnocených zimních období byl povrchový odtok $\mathrm{z}$ víceletých pícnin průkazně vyšší (2,05-krát) než z pšenice. Průměrný koeficient povrchového odtoku u ozimé pšenice byl 0,239 a u víceletých pícnin 0,489 .

Je-li však zima tuhá a dostatečně dlouhá s větším počtem dílčích oblev doprovázených dešti, pak filtrační deformace půdním ledem může dosáhnout stavu, kdy se půda stává pro vodu zcela nepropustnou bez ohledu na to, byla-li původně kyprá, nebo ulehlá. Součinitele povrchového odtoku pak dosahují hodnot blízkých 1,0. V důsledku povrchových odtokủ srážkových vod jsou pak svahové pozemky ochuzovány o vodu a naopak pozemky $\mathrm{v}$ údolních nivách nebo $\mathrm{v}$ terénních depresích, kde se tvoří laguny, trpí její přebytkem. Ve vyšších polohách s vyšší sněhovou pokrývkou je proces promrzání půdy a vzniku nepropustné ledové vrstvy omezen a koeficient povrchového odtoku nabývá menších hodnot, než v nižších polohách. 